(c) American Dairy Science Association, 2004.

\title{
Evaluation of Salt Whey as an Ingredient in Processed Cheese
}

\author{
R. Kapoor and L. E. Metzger \\ MN-SD Dairy Foods Research Center, \\ Department of Food Science and Nutrition, \\ University of Minnesota, St. Paul 55108
}

\begin{abstract}
The objective of this research was to determine whether salt whey, obtained from a traditional Cheddar cheese manufacturing process, could be used as an ingredient in processed cheese. Due to its high salinity level, salt whey is underutilized and leads to disposal costs. Consequently, alternative uses need to be pursued. The major components of salt whey (salt and water) are used as ingredients in processed cheese. Three replicates of pasteurized processed cheese (PC), pasteurized processed cheese food (PCF), and pasteurized processed cheese spread (PCS) were manufactured. Additionally, within each type of processed cheese, a control formula $(\mathrm{CF})$ and a salt whey formula (SW) were produced. For SW, the salt and water in the CF were replaced with salt whey. The composition, functionality, and sensory properties of the $\mathrm{CF}$ and SW treatments were compared within each type of processed cheese. Mean melt diameter obtained for the $\mathrm{CF}$ and SW processed cheeses were 48.5 and $49.4 \mathrm{~mm}$, respectively, for PC, and they were 61.6 and $63 \mathrm{~mm}$, respectively, for PCF. Tube-melt results for PCS was 75.1 and 79.8 $\mathrm{mm}$ for $\mathrm{CF}$ and $\mathrm{SW}$ treatments, respectively. The mean texture profile analysis (TPA) hardness values obtained, respectively, for the $\mathrm{CF}$ and $\mathrm{SW}$ treatments were $126 \mathrm{~N}$ and $115 \mathrm{~N}$ for $\mathrm{PC}, 62 \mathrm{~N}$ and $60 \mathrm{~N}$ for $\mathrm{PCF}$, and $12 \mathrm{~N}$ and $12 \mathrm{~N}$ for PCS. There were no significant differences in composition or functionality between the $\mathrm{CF}$ and SW within each variety of processed cheese. Consequently, salt whey can be used as an ingredient in PC without adversely affecting processed cheese quality.
\end{abstract}

(Key words: salt whey, processed cheese)

Abbreviation key: $\mathbf{C F}=$ control formula cheese, $\mathbf{P C}=$ pasteurized processed cheese, $\mathbf{P C F}=$ pasteurized processed cheese food, $\mathbf{P C S}=$ pasteurized processed cheese spread, $\mathbf{S W}=$ salt whey formula, TPA = texture profile analysis.

Received August 26, 2003.

Accepted October 8, 2003.

Corresponding author: L. E. Metzger; e-mail: lmetzger@umn.edu.

\section{INTRODUCTION}

Salting is one of the final steps in the cheese manufacturing process in various cheeses such as Cheddar. When salt is dispersed on the milled curd during dry salting, it dissolves into the moisture on the surface and subsequently diffuses into the curd particles. This leads to a shrinkage and syneresis of the curd particles, resulting in the expulsion of whey. Most of this whey is drained or physically expelled during pressing (Sutherland, 1974; Gilbert, 1979). The stream of whey produced during this step is known as "salt whey." During Cheddar cheese manufacture, approximately 7 to $9 \mathrm{~kg}$ of salt whey is produced per $100 \mathrm{~kg}$ of curd salted (Sutherland, 1974). Approximately 20 to $40 \%$ of salt whey is obtained during the mellowing stage, whereas 60 to $80 \%$ is obtained during the pressing stage. The salt content of commingled salt whey from Cheddar and Colby cheese manufacture is approximately 4 to $10 \%$ (Sutherland, 1974; Gregory, 1988). Salt whey, unlike sweet whey, cannot be conveniently processed because of its high salinity level (Sanderson et al., 1996). Moreover, it has a high biological oxygen demand and chemical oxygen demand, which make its disposal a problem (Zayed and Winter, 1995). In the past, most cheese manufacturing facilities in the United States performed land spreading of salt whey; however, this practice increases the chloride levels of soil, and it elevates the risk of crop damage (Parmentier, 2000; Rao and Wendorff, 2003). Gregory (1988) used a nano-filtration membrane process to remove $90 \%$ of the salt from salt whey and in the process recovered $80 \%$ of the nonsalt whey solids, which were then incorporated into the sweet whey stream. Sanderson et al. (1996) used a similar nanofiltration process, except that they also concentrated the permeate containing the salt by evaporation and used it to salt additional cheese. Other researchers have demonstrated that salt whey can be used to produce lactic acid using immobilized cultures (Zayed and Zahran, 1991; Zayed and Winter, 1995) or produce yeast protein (Zall and El-Samragy, 1988). In spite of this previous research, salt whey is still an underutilized whey stream and alternative uses need to be explored.

One possible alternative for salt whey is to use it as an ingredient in processed cheese. Processed cheese is 
a generic term used to describe 3 separate categories of cheese. These categories are pasteurized processed cheese (PC), pasteurized processed cheese food (PCF), and pasteurized processed cheese spread (PCS) (Code of Federal Regulations, 2003). According to the Code of Federal Regulations (2003), these 3 categories differ on the basis of the requirements for minimum fat content on DM basis and the maximum allowed moisture content as well as the quantity and the number of optional ingredients that can be used. A typical processed cheese formulation contains substantial amounts of salt and water, and it may be possible to replace the salt and water with salt whey.

Salt whey as an ingredient can pose certain concerns when utilized in processed cheese. In addition to salt and water, salt whey also has other whey solids, including whey proteins and lactose that could potentially alter the quality of processed cheese. Various researchers have studied the influence of incorporation of whey proteins on the functionality of processed cheese (Gupta and Reuter, 1992; Thapa and Gupta, 1992). Gupta and Reuter (1992) ultrafiltered whey to produce a concentrate with $20 \%$ whey proteins and 5.8\% lactose, which was utilized as an ingredient to replace $20 \%$ of the solids in a PCF formula. They determined that the addition of approximately $2.2 \%$ whey protein in the final PCF with an average moisture content of $45 \%$ did not affect the quality of processed cheese. The level of lactose present in processed cheese is critical because an excess amount can result in the formation of crystals. This issue has been addressed by other researchers who determined that lactose crystallization in processed cheese depends on the maximum concentration of lactose that is soluble in the water phase of processed cheese (Thomas, 1973; Zehren and Nusbaum, 2000). The maximum concentration of lactose that is soluble in water is $17 \%$ (Harper, 1992). Therefore, as a general guideline, it is important to maintain the amount of lactose in the water phase of processed cheese to less than $17 \%$ in order to avoid lactose crystallization. As an example, Berger et al. (1998) suggests that in order to maintain the quality of processed cheese, the maximum lactose content in the final product should be less than $4 \%$. A processed cheese with $4 \%$ lactose would have $10 \%$ lactose in the water phase (4\% lactose $/ 40 \%$ moisture), which is well within the maximum solubility of $17 \%$.

Fortunately, whey solids are already present in process cheese because whey is a permitted ingredient in PCF and PCS (Code of Federal Regulations, 2003). Whey solids are also found in PC because they are present in liquid and dried cream, which are permitted in PC. Additionally, some processed cheese plants also use whey solids as a carrier for color in PC. Conse- quently, when salt whey is utilized in processed cheese, the whey protein and lactose present can be accounted for by reducing the amount of other ingredients that contain whey protein and lactose.

Another potential problem that might be associated with salt whey utilization is its sanitary collection and storage. Modern cheese manufacturing plants are highly automated and utilize salting and mellowing conveyors, which have improved the sanitary collection and segregation of salt whey (Scherping et al., 1999). There have also been marked advances in the field of whey handling systems at dairy plants (Hutson, 1998). These advances in cheese manufacturing systems have largely eliminated problems associated with the sanitary processing and handling of salt whey. Therefore, utilization of salt whey as an ingredient in processed cheese manufacture appears to be an attractive alternative.

The objective of this study was to evaluate the feasibility of using salt whey as an ingredient in processed cheese manufacture and to determine any influences on the functional and sensory properties of the resulting processed cheese.

\section{MATERIALS AND METHODS}

\section{Experimental Design}

Two treatments for each of the 3 categories (PC, PCF, and PCS) of processed cheese were produced. Treatment 1 within each category utilized a control formula (CF), whereas treatment 2 within each category utilized salt whey as an ingredient (SW). Processed cheese manufacture was repeated on 3 different days utilizing 3 different batches of salt whey and 3 different young and aged natural cheeses.

\section{Salt Whey Collection and Processed Cheese Manufacture}

The salt whey used in this study was collected from the salting and the pressing steps from milled curd Cheddar cheese manufacture at the University of Minnesota pilot plant. It was filtered, commingled, pasteurized $\left(63^{\circ} \mathrm{C} / 30 \mathrm{~min}\right)$, and stored at $4^{\circ} \mathrm{C}$ for 16 to $22 \mathrm{~h}$ before use.

The processed cheese formulations were developed using Techwizard, which is an Excel-based formulation/ nutrition software program (Metzger, 2003) provided by Owl Software (Lancaster, PA). Techwizard has been shown to be effective for goal-oriented formulations in ice cream in which different ingredient blends were successfully formulated to achieve the same final sweetness level, texture, and sensory properties (Phillips and Roland, 1999). The detailed ingredient blend and for- 
Table 1. Mean salt whey and control formulations for pasteurized processed cheese (PC) pasteurized processed cheese food (PCF), and pasteurized processed cheese spread (PCS).

\begin{tabular}{|c|c|c|}
\hline Ingredients, $\%$ & Control & Salt whey \\
\hline \multicolumn{3}{|l|}{$\mathrm{PC}$ formula } \\
\hline Young cheese $(<1 \mathrm{mo})$ & 51.5 & 51.4 \\
\hline Aged cheese (6-12 mo) & 28.6 & 28.3 \\
\hline Dried cream & 5.8 & 5.3 \\
\hline Butter oil (anhydrous) & 1.9 & 2.1 \\
\hline Enzyme modified cheese & 0.4 & 0.4 \\
\hline Sodium phosphate, dibasic & 2.25 & 2.25 \\
\hline Salt & 0.5 & - \\
\hline Water & 9.0 & 4.3 \\
\hline Salt whey & - & 5.8 \\
\hline Total & 100.0 & 100.0 \\
\hline \multicolumn{3}{|l|}{ PCF formula } \\
\hline Young cheese $(<1 \mathrm{mo})$ & 57.1 & 56.6 \\
\hline Aged cheese (6-12 mo) & 13.3 & 13.3 \\
\hline Nonfat dried milk (NFDM) & 3.0 & 3.0 \\
\hline Whey powder & 5.0 & 4.6 \\
\hline Butter oil (anhydrous) & 1.4 & 1.4 \\
\hline Enzyme modified cheese & 0.4 & 0.4 \\
\hline Sodium citrate & 2.5 & 2.5 \\
\hline Salt & 0.6 & - \\
\hline Water & 16.6 & 10.6 \\
\hline Salt whey & - & 7.6 \\
\hline Total & 100.0 & 100.0 \\
\hline \multicolumn{3}{|l|}{ PCS formula } \\
\hline Young cheese $(<1 \mathrm{mo})$ & 50.0 & 50.0 \\
\hline Aged cheese (6-12 mo) & 10.0 & 10.1 \\
\hline Nonfat dried milk (NFDM) & 4.0 & 3.4 \\
\hline Whey powder & 3.6 & 3.5 \\
\hline Butter oil (anhydrous) & 0.95 & 0.75 \\
\hline Whey protein concentrate & 1.5 & 1.5 \\
\hline Sodium phosphate, dibasic & 2.25 & 2.25 \\
\hline Salt & 0.8 & - \\
\hline Lactic acid & 0.3 & 0.28 \\
\hline Potassium sorbate & 0.2 & 0.2 \\
\hline Water & 26.4 & 18.5 \\
\hline Salt whey & - & 9.5 \\
\hline Total & 100.0 & 100.0 \\
\hline
\end{tabular}

mulations for PC, PCF, and PCS are indicated in Table 1. The formulation program was used to balance the salt, moisture, fat, whey protein, and lactose in the control and salt whey treatments for each variety of processed cheese to the values as indicated in Table 2 . Young and aged cheeses used in the ingredient blend were obtained from Bongards Creameries (Bongards, $\mathrm{MN}$ ) and Land O' Lakes, Inc. (St. Paul, MN), respectively. Young and aged cheese used in each replicate

Table 2. Component balance used to formulate the control formula cheese $(\mathrm{CF})$ and salt whey formula (SW) treatments for pasteurized processed cheese (PC) pasteurized processed cheese food (PCF), and pasteurized processed cheese spread (PCS).

\begin{tabular}{lrrr}
\hline Component (\% of final product) & PC & PCF & PCS \\
\hline Moisture, \% & 39.5 & 43.5 & 49.5 \\
Fat, \% & 30.0 & 25.0 & 20.0 \\
Salt, \% & 2.0 & 2.0 & 2.0 \\
Whey protein, \% & 0.5 & 1.1 & 1.5 \\
Lactose, \% & 2.0 & 5.1 & 5.5 \\
\hline
\end{tabular}

were from different batches. Each young cheese was less than 1 mo old and had a mean moisture, fat, salt, and $\mathrm{pH}$ of $37.15 \%(\mathrm{SD}=1.01 \%), 33.2 \%(\mathrm{SD}=0.97 \%)$, $1.65 \%(\mathrm{SD}=0.16 \%)$, and $5.2(\mathrm{SD}=0.1)$, respectively. The aged cheese used in the blend was 6 to 12 mo old and had a mean moisture, fat, salt, and $\mathrm{pH}$ of $37.09 \%$ $(\mathrm{SD}=0.75 \%), 33.39 \%(\mathrm{SD}=0.54 \%), 1.57 \%(\mathrm{SD}=0.1 \%)$, and $5.06(\mathrm{SD}=0.11)$, respectively. The emulsifying salts used were sodium phosphate (dibasic) (Astaris LLC, St. Louis, MO) for PC and PCS and trisodium citrate (duohydrate) (Archer Daniels Midland Company, Decatur, IL) for PCF. Other ingredients were nonfat dried milk (low heat) (Dairy America, Fresno, CA), anhydrous butter oil (Mid-America Farms, Springfield, MO), sweet whey powder (Bongards Creameries), whey protein concentrate (34\%) (Davisco International Inc., Eden Prairie, MN), enzyme-modified cheese (Land O' Lakes, Inc.), lactic acid (Fisher Chemicals, Fair Lawn, NJ), and potassium sorbate (United Foods, Inc., New Brunswick, NJ). Dried cream was prepared by standardizing butter oil to $40 \%$ fat with nonfat dried milk.

All treatments were manufactured in $4.5-\mathrm{kg}$ batches using a Blentech twin screw cooker blender (Blentech Corporation, Rohnert Park, CA). The ingredients were tempered at room temperature for $1 \mathrm{~h}$, followed by dry blending at $40^{\circ} \mathrm{C}$ for $3 \mathrm{~min}$ in the cooker. Emulsifying salts were dissolved in water or salt whey $\left(40^{\circ} \mathrm{C}\right)$ depending on the treatment and added to the dry ingredient blend followed by cooking. The cook temperature, cook time (the time for which the processed cheeses were held after they reached cook temperature), and revolutions per minute used for each category of processed cheese were 77 to $80^{\circ} \mathrm{C}, 4 \mathrm{~min}$, and $120 \mathrm{rpm}$ for $\mathrm{PC} ; 77$ to $80^{\circ} \mathrm{C}, 4 \mathrm{~min}$, and $140 \mathrm{rpm}$ for PCF; and 87 to $90^{\circ} \mathrm{C}, 4 \mathrm{~min}$, and $200 \mathrm{rpm}$ for PCS, respectively. These conditions were based on the recommendations by Kosikowski and Mistry (1997). The cooked processed cheeses were filled hot in 1-kg boxes and transferred to the cold room $\left(4^{\circ} \mathrm{C}\right)$ after $15 \mathrm{~min}$. All the cooked processed cheeses were stored at $4^{\circ} \mathrm{C}$ until analysis.

\section{Chemical Analyses}

The moisture content of Cheddar cheese (young and aged) was determined gravimetrically by heating a 2g sample of cheese at $100^{\circ} \mathrm{C}$ for $24 \mathrm{~h}$ in a forced draft oven (model OV-490A-2; Blue M, Blue Island, IL). The moisture content of salt whey was determined using a microwave oven (CEM Corp., Matthews, NC) by heating 3 to $4 \mathrm{~g}$ of the sample at $100 \%$ power for $4 \mathrm{~min}$ (Green and Park, 1980; Barbano and Della Valle, 1984). The moisture content of processed cheese was analyzed using a vacuum oven as described by Bradley, Jr. and Vanderwarn (2001). Fat content of the young and aged 
cheese, salt whey, and the processed cheese were determined using the Mojonnier method (Atherton and Newlander, 1977). Salt content was measured using a Corning Chloride Analyzer 926, and $\mathrm{pH}$ was measured with a Corning pH/ion meter model 450 (Corning Glass Works, Medfield, MA) with a Sentron streamline $\mathrm{pH}$ probe (Sentron, Gig Harbor, WA). The protein content of the processed cheeses was determined using the Dumas combustion method (Wiles et al., 1998). A 0.15-g sample was weighed into a tinfoil cap and analyzed in triplicate using a Leco FP-428 Dumas Combustion Unit (Leco Corporation, St. Joseph, MI). Prior to the analysis, the combustion unit was calibrated using EDTA (Leco Corporation). The lactose content of the processed cheeses was determined using an enzymatic test kit (Boehringer Manheim, Indianapolis, IN). Lactose was extracted from the processed cheeses according to the manufacturer's specifications for processed cheese, except a sample size of $0.75 \mathrm{~g}$ was used and the sample was ground with the reagents and incubated for $15 \mathrm{~min}$ at $70^{\circ} \mathrm{C}$.

\section{Functional Analyses}

Tests for meltability. The Schreiber melt test was performed on PC and PCF using the modified method from Muthukumarappan et al. (1999). Cheese was cut into discs with a 34-mm diameter and a 7-mm height. Five discs of equal weights were randomly selected and placed on aluminum plates, covered with a glass petri dish, and tempered at room temperature for $30 \mathrm{~min}$. The average weight of the discs was approximately 8 $\mathrm{g}$ for $\mathrm{PC}$ and $7 \mathrm{~g}$ for PCF. Tempered samples were then heated in a forced draft oven (model OV-490A-2; Blue $\mathrm{M}$, Blue Island, IL) at $100^{\circ} \mathrm{C}$ for $7 \mathrm{~min}$. The meltability of cheese was determined by measuring the final diameter of the cheese discs at 4 different locations after they cooled to room temperature, and the average value (in millimeters) was reported as meltability of cheese.

The tube-melt test was performed on PCS using a method modified from Olson and Price (1958). Five samples of each PCS ( $20 \mathrm{~g}$ each, made up of small chunks of approximately $5 \times 5 \times 5 \mathrm{~mm}$ in size) were weighed into 38- $\times 200-\mathrm{mm}$ test tubes (Fisher Scientific), with a reference line etched $25 \mathrm{~mm}$ from the bottom. The samples were then packed to the etched reference line at the bottom of the tube. Tubes were sealed with a 1-hole rubber stopper and placed vertically (with the cheese end down) at $4^{\circ} \mathrm{C}$ for $30 \mathrm{~min}$. The tubes were then placed on a tube rack in a horizontal position and heated in a forced draft oven (model OV-490A-2; Blue $\mathrm{M}$, Blue Island, IL) at $110^{\circ} \mathrm{C}$ for $8 \mathrm{~min}$. The samples were then cooled to room temperature and the meltability of cheese was determined by measuring the "flow" of the heated cheese from the etched line. The results were reported as length of flow in millimeters by averaging the values obtained from 5 samples.

Rapid visco analyzer melt test. A rapid visco analyzer (Newport Scientific Pty. Ltd., Warriewood, Australia) was used to determine the apparent viscosity of PC, PCF, and PCS during a heating, holding, and cooling profile described by Rosenberg et al. (2002). In the rapid visco analyzer melt test, $14 \mathrm{~g}$ of cheese and $1 \mathrm{~g}$ of propylene glycol (Fisher Scientific) was used for PC and PCF, whereas $15 \mathrm{~g}$ of cheese was used for PCS. During the test, the canister temperature was increased, from $25^{\circ} \mathrm{C}$ to a peak temperature of $85^{\circ} \mathrm{C}$ for $\mathrm{PC}$ and PCF and $90^{\circ} \mathrm{C}$ for PCS, over 5 min; held for 3 min at the peak temperature; and finally cooled to $25^{\circ} \mathrm{C}$ over $6 \mathrm{~min}$. The stirring speed was held at $0 \mathrm{rpm}$ for $30 \mathrm{~s}, 20 \mathrm{rpm}$ for $30 \mathrm{~s}, 100 \mathrm{rpm}$ for $1 \mathrm{~min}$, and 300 rpm for the remainder of the test. During stirring the apparent viscosity was continuously measured. The minimum apparent viscosity during the holding period at the peak temperature and the time required to reach an apparent viscosity of $5000 \mathrm{cP}$ during the cooling period were collected from the apparent viscosity vs. time curve and were referred to as hot apparent viscosity and solidification point, respectively (Rosenberg and Metzger, 2003). According to Rosenberg and Metzger (2003), hot apparent viscosity is a measure of how well a cheese flows at a fixed temperature, and the solidification point is a measure of how quickly a melted cheese solidifies during cooling.

Texture profile analysis hardness. For texture profile analysis (TPA), 5 representative samples of PC and $\mathrm{PCF}$ were cut into cylinders with a $20-\mathrm{mm}$ diameter and 20-mm height, whereas the PCS was cut into 20$\mathrm{mm}$ cubes. Samples were wrapped with Saran Wrap and held at $4^{\circ} \mathrm{C}$ for 30 min before the TPA analysis. The TPA analysis was performed immediately using a TA.XT2 Texture Analyzer (Texture Technologies Corp., Scarsdale, NY/Stable Microsystems, Godalming, UK) as described by Drake et al. (1999). Test conditions were: Uniaxial 2 bite compression with 50-mm diameter Cylindrical flat probe (TA-25); Compression of $80 \%$ for PC and PCF and 70\% for PCS; and Crosshead speed: $0.8 \mathrm{~mm} / \mathrm{s}$. The TPA-hardness was determined as described by Breene (1975) and is a measure of the unmelted texture of a cheese and describes cheese firmness (Breene, 1975).

\section{Sensory Evaluation}

A triangle test was performed at the Sensory Center (Department of Food Science and Nutrition, University of Minnesota) to compare the flavor and textural attributes of the CF and SW treatments for each variety of 
Table 3. The mean $(\mathrm{N}=3)$ composition $^{1}$ of pasteurized processed cheese $(\mathrm{PC})$ pasteurized processed cheese food (PCF), and pasteurized processed cheese spread (PCS).

\begin{tabular}{|c|c|c|c|c|c|c|}
\hline \multirow{2}{*}{$\begin{array}{l}\text { Cheese } \\
\text { composition }\end{array}$} & \multicolumn{2}{|c|}{$\mathrm{PC}$} & \multicolumn{2}{|c|}{$\mathrm{PCF}$} & \multicolumn{2}{|c|}{ PCS } \\
\hline & Control & Salt whey & Control & Salt whey & Control & Salt whey \\
\hline Moisture, \% & 39.5 & 39.5 & 43.5 & 43.5 & 49.4 & 49.6 \\
\hline Fat, $\%$ & 31.5 & 31.2 & 25.3 & 24.9 & 21.4 & 21.2 \\
\hline Salt, \% & 1.97 & 1.97 & 2.00 & 2.05 & 2.03 & 2.02 \\
\hline $\mathrm{pH}$ & 5.69 & 5.62 & 5.61 & 5.64 & 5.56 & 5.55 \\
\hline Protein, \% & 20.3 & 20.2 & 18.2 & 18.4 & 16.3 & 16.2 \\
\hline Lactose, \% & 2.00 & 2.00 & 5.16 & 5.12 & 5.45 & 5.24 \\
\hline
\end{tabular}

${ }^{1}$ There was no significant difference between the treatments for PC, PCF, and PCS $(P>0.05)$.

processed cheese. Each replicate was analyzed independently using a panel of 25 judges who were provided with 3 samples, 2 of which were the same (i.e., $2 \mathrm{SW}$ samples and $1 \mathrm{CF}$ sample or $2 \mathrm{CF}$ samples and $1 \mathrm{SW}$ sample). Each judge was asked to identify the odd sample. The nature of the odd sample and the order of samples in each set were randomized. Normal distribution, as an approximation for binomial distribution, was used for data analysis. Statistics were performed at the $95 \%$ confidence level. Cheeses were maintained at $4^{\circ} \mathrm{C}$ prior to analysis.

\section{Statistical Analysis}

A randomized complete block design with 2 treatments, CF and SW, was used for each of the 3 varieties: PC, PCF, and PCS. Each replicate, which was manufactured on a different day, was treated as the blocks of the design. The ANOVA was performed to obtain the mean square and $P$-values using Macanova 4.12 software (School of Statistics, University of Minnesota, Minneapolis). The comparisons were made at the 0.05 level of significance. The results were considered significant at $P<0.05$.

\section{RESULTS AND DISCUSSIONS}

\section{Composition of Salt Whey and Processed Cheese}

Mean values for moisture, fat, salt, and the $\mathrm{pH}$ of the commingled salt whey were $82.21(\mathrm{SD}=2.34 \%), 1.69$
$(\mathrm{SD}=0.58 \%), 8.71(\mathrm{SD}=1.53 \%)$, and $5.21(\mathrm{SD}=0.08)$, respectively. The mean values for moisture, fat, salt, $\mathrm{pH}$, protein, and lactose for the 2 treatments of processed cheese, $\mathrm{CF}$ and $\mathrm{SW}$, for each of the varieties of processed cheese (PC, PCF, and PCS) are indicated in Table 3. All processed cheeses met the legal standards of identity as specified by the Code of Federal Regulations (2003). There was no significant difference in processed cheese composition between the treatments $(P$ $>0.05$ ) for each of the 3 varieties of processed cheese.

\section{Processed Cheese Functional Properties}

Processed cheese. The mean values of the functional properties of PC including meltability, TPA-hardness, hot apparent viscosity, and solidification point are shown in Table 4. No significant differences in meltability, TPA-hardness, hot apparent viscosity, or solidification point were found between the treatments $(P>0.05)$. The mean square values and the $P$-values for functional properties with regards to $\mathrm{PC}$ are indicated in the Table 5. Statistics revealed a significant replication effect in the firmness (TPA-hardness) of PC. The significant replication effect was expected because different natural cheese was used for each replicate.

Processed cheese food. The mean values of the various functional properties of PCF are also shown in Table 4. No significant differences in meltability, TPA-hardness, hot apparent viscosity, or solidification point were found between the treatments $(P>0.05)$. The mean

Table 4. The mean $(\mathrm{N}=3)$ values of the functional properties ${ }^{1}$ of pasteurized processed cheese (PC) pasteurized processed cheese food (PCF), and pasteurized process cheese spread (PCS).

\begin{tabular}{|c|c|c|c|c|c|c|}
\hline \multirow{2}{*}{$\begin{array}{l}\text { Cheese } \\
\text { property }\end{array}$} & \multicolumn{2}{|c|}{$\mathrm{PC}$} & \multicolumn{2}{|c|}{ PCF } & \multicolumn{2}{|c|}{ PCS } \\
\hline & Control & Salt whey & Control & Salt whey & Control & Salt whey \\
\hline Meltability, mm & 48.5 & 49.4 & 61.6 & 63 & 75.1 & 79.8 \\
\hline TPA-hardness, $\mathrm{N}$ & 126 & 115 & 62 & 60 & 12 & 12 \\
\hline Hot apparent viscosity, $\mathrm{cP}$ & 754 & 779 & 477 & 476 & 354 & 361 \\
\hline Solidification point, min & 11.13 & 11.14 & 11.72 & 11.75 & 11.84 & 11.88 \\
\hline
\end{tabular}

${ }^{1}$ There was no significant difference between the treatments for PC, PCF, and PCS $(P>0.05)$. 


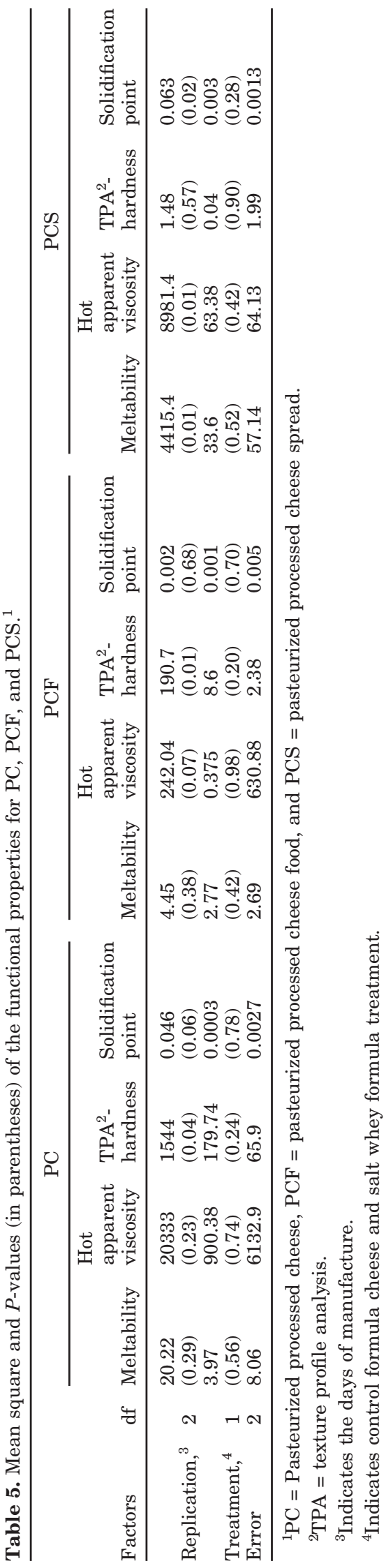

square values and the $P$-values for functional properties with regards to $\mathrm{PCF}$ are indicated in the Table 5. Statistics revealed a significant replication effect in the firmness (TPA-hardness) of PCF. As was the case with PC, the significant replication effect was expected because a different natural cheese was used for each replicate.

Processed cheese spread. The mean values of the various functional properties of PCS are indicated in Table 4. No significant differences in meltability, TPAhardness, hot apparent viscosity, or solidification point were found between the treatments $(P>0.05)$. The mean square values and the $P$-values for functional properties with regards to PCS are indicated in the Table 5. Statistics revealed a significant replication effect (again resulting from the different natural cheese used for each replicate) in the meltability, hot apparent viscosity, and solidification point of PCS.

As mentioned previously, statistics (Table 5) revealed a significant replication effect on the firmness in the case of PC and PCF. However, in the case of PCS there was a significant replication effect on the melt textural properties (meltability, hot apparent viscosity, and solidification point) within each type of processed cheese. All the replicates used in this study were balanced for moisture, fat, salt, whey protein, and lactose; however, different young and aged natural cheeses were used for each replicate. Consequently, the observed replication effect on the functional properties may be due to variations in the properties of the natural cheese used for each replicate (i.e., calcium phosphate content and the relative casein content) (Berger et al., 1998).

\section{Processed Cheese Sensory Properties}

The results of the triangle test for $\mathrm{CF}$ and $\mathrm{SW}$ for $\mathrm{PC}, \mathrm{PCF}$, and PCS are indicated in the Table 6. There was no significant difference $(P>0.05)$ in the sensory properties in the case of $\mathrm{PC}$ and $\mathrm{PCF}$ and 2 replicates of the PCS. However, a sensory difference between the treatments was detected in the case of replicate \#1 for PCS. The reason that panelists were able to detect a sensory difference between the salt whey and control formula in one replicate of PCS is unknown. However, we speculate that variation in the manufacturing process between the 2 treatments of PCS within that replicate may have been responsible for the observed difference. Processing conditions such as cook temperature, cook time, and the amount of shear provided during manufacture can play a major role in controlling the emulsion formation and the resulting functional properties of processed cheese (Rayan et al., 1980; Berger et al., 1998; Swenson et al., 2000). Because no sensory differences were observed in any of the replicates of PC and PCF or in 2 replicates of PCS, we have concluded 
Table 6. Number of correct responses, $\mathrm{Z}$ scores and the $P$-values for each replicate from the triangle test performed on pasteurized processed cheese (PC) pasteurized processed cheese food (PCF), and pasteurized processed cheese spread (PCS).

\begin{tabular}{|c|c|c|c|c|c|c|c|c|c|}
\hline \multirow[b]{2}{*}{ Replicate } & \multicolumn{3}{|c|}{$\mathrm{PC}$} & \multicolumn{3}{|c|}{$\mathrm{PCF}$} & \multicolumn{3}{|c|}{ PCS } \\
\hline & \# Correct & Z score & $P$-value & \# Correct & Z score & $P$-value & \# Correct & $\mathrm{Z}$ score & $P$-value \\
\hline 1 & 9 & 0.07 & 0.47 & 9 & 0.07 & 0.47 & 15 & 2.61 & 0.00 \\
\hline 2 & 10 & 0.49 & 0.31 & 9 & 0.07 & 0.47 & 10 & 0.49 & 0.31 \\
\hline 3 & 11 & 0.92 & 0.18 & 9 & 0.07 & 0.47 & 11 & 0.92 & 0.18 \\
\hline
\end{tabular}

that utilization of salt whey does not influence the sensory properties of processed cheese.

\section{Impact of Salt Whey Utilization in Processed Cheese}

In this study, salt whey was used at a rate of 5.8, 7.6, and 9.5\%, respectively, in PC, PCF, and PCS formulations (Table 1). Moreover, salt whey was utilized with minimal processing and was simply filtered and pasteurized prior to use. In 2000, the total salt whey produced from Cheddar cheese manufacture was approximately 127 million $\mathrm{kg}$. The total PC production was 635 million $\mathrm{kg}$ and total production of PCF and PCS together was 387 million $\mathrm{kg}$. At the level utilized in this study for PC (5.8\%) and assuming an average value of $8.6 \%$ for PCF and PCS together, approximately $55 \%$ of the salt whey produced from Cheddar cheese in the United States could be used in processed cheese manufacture. Additionally, the above data do not include processed cheese products and imitation cheeses, which also have significant potential to utilize salt whey as an ingredient.

\section{CONCLUSIONS}

Incorporation of salt whey in processed cheese does not have a significant effect on the quality of processed cheese and can be effectively utilized as an ingredient in all 3 varieties of processed cheese. This study indicates that 5.8, 7.6, and $9.5 \%$ salt whey can be utilized in PC, PCF, and PCS formulations, respectively. Consequently, utilization of salt whey as an ingredient in processed cheese appears to be an attractive alternative and could significantly reduce the need and costs for disposal of salt whey.

\section{REFERENCES}

Atherton, H. V., and J. A. Newlander. 1977. Tests for fat: Babcock, Gerber and Mojonnier. Pages 71-116 in Chemistry and Testing of Dairy Products. 4th ed. AVI Publ. Co., Inc., Westport, CT.

Barbano, D. M., and M. E. Della Valle. 1984. Microwave drying to determine the solids content of milk and cottage and cheddar cheese. J. Food Prot. 47:272-278.
Berger, W., H. Klostmeyer, K. Merkenich, and G. Uhlmann. 1998. Process Cheese Manufacture-A JOHA Guide. BK Guilini Chemie Gmbh \& Co. OHG, Ladenberg, Germany.

Bradley, R. L., Jr., and M. A. Vanderwarn. 2001. Determination of moisture in cheese and cheese products. J. AOAC 84:570-592.

Breene, W. M. 1975. Application of texture profile analysis to instrumental food texture evaluation. J. Texture Stud. 6:53-82.

Code of Federal Regulations. 2003. Section 133.169 US Dept. Health Human Services, Washington, DC.

Drake, M. A., P. D. Gerard, V. D. Truong, and C. R. Daubert. 1999. Relationship between instrumental and sensory measurements of cheese texture. J. Texture Stud. 30:451-476.

Gilbert, R. W. 1979. Mechanism of salt absorption into Cheddar cheese. Marschall Italian and Speciality Cheese Seminars. Online Available: http://www.marschall.com/marschall/proceed/pdf/79 60.pdf. Accessed July 18, 2003.

Green, W. C., and K. K. Park. 1980. Comparison of AOAC, microwave and vacuum methods for determining total solids in milk. J. Food Prot. 43:782-783.

Gregory, A. G. 1988. Desalination of sweet-type whey salt dripping for whey solids recovery. Bull. Int. Dairy Fed. 212:38-49.

Gupta, V. K., and H. Reuter. 1992. Processed cheese foods with added whey protein concentrates. Lait 72:201-212.

Harper, W. V. 1992. Lactose and lactose derivatives. Pages 326-328 in Whey and Lactose Processing. J.G. Zadow, ed. Elsevier Science Publishers Ltd, New York, NY.

Hutson, T. 1998. The preparation of whey for the production of whey products. Marschall Italian and Speciality Cheese Seminars. Online Available: http://www.marschall.com/marschall/proceed/pdf/ 98/98 02.pdf. Accessed July 18, 2003.

Kosikowski, F. V., and V. V. Mistry. 1997. Process cheese and related products. Pages 156-161 in Cheese and Fermented Milk Foods. Vol. 2. 3rd ed. F V Kosikowski, L.L.C, Westport, CT.

Metzger, L. E. 2003. Nutrition labeling using a computer program. Pages 1-6 in Food Analysis Laboratory Manual. S. S. Nielsen, ed. Kluwer Academic, New York, NY.

Muthukumarappan, K., Y. C. Wang, and S. Gunasekaran. 1999. Modified Schreiber test for evaluation of Mozzarella cheese meltability. J. Dairy Sci. 82:1068-1071.

Olson, N. F., and W. V. Price. 1958. A melting test for pasteurized process cheese spread. J. Dairy Sci. 41:999-1000.

Parmentier, K. 2000. Determination of volume of industrial waste from Wisconsin's dairy products industry. University of Wisconsin, Green Bay. Online Available: http://www.wastenot-organics. wisc.edu/library/whey.htm. Accessed July 18, 2003.

Phillips, L. G., and A. M. Roland. 1999. Development of a software program for goal oriented formulation. IFT Annual Meeting, 1999. Chicago, IL. Online. Available: http://www.owlsoft.com/ Goal1.pdf. Accessed July 18, 2003.

Rao, R. D., and W. L. Wendorff. 2003. Compositional differences between whey, salty whey, and press whey from commercial manufacture of Cheddar cheese. J. Dairy Sci. 86(Suppl. 1):365. (Abstr.)

Rayan, A. A., M. Kalab, and C. A. Ernstrom. 1980. Microstructure of process cheese. Scan. Electron Microsc. III:635-643.

Rosenberg, L. A., and L. E. Metzger. 2003. Comparison of the melting properties of process cheese using a Rapid Visco Analyzer (RVA) and the Schreiber melt test. J. Dairy Sci. 86 (Suppl. 1):40. (Abstr.) 
Rosenberg, L. A., L. E. Metzger, M. R. Acharya, and V. V. Mistry. 2002. Evaluation of process cheese melting characteristics using a Rapid Visco Analyzer. Page 23 in Book of Abstracts, 2002 IFT Annual Meeting and Food Expo, Anaheim, CA.

Sanderson, W. B., A. P. Brady, G. F. Whitehead, I. J. Oldham, and I. P. Brockwell, inventors. 1996. Recycling salt solution in cheese processing and apparatus therefore. Murray Goulburn Co-Operative Co. Limited, Australia, assignee. US Pat. No. 5,73,237.

Scherping, V. J., G. H. Schwinghammer, and G. L. Starkson, inventors. 1999. Method for processing cheese curds. Walker Stainless Equipment Company, Inc., New Lisbon, Wisconsin, assignee. US Pat. No. 5,906,854

Sutherland, B. J. 1974. Control of salt absorption and whey drainage in Cheddar cheese manufacture. Aust. J. Dairy Technol. 29:86-93.

Swenson, B. J., W. L. Wendorff, and R. C. Lindsay. 2000. Effects of ingredients on the functionality of fat-free process cheese spreads. J. Food Sci. 65:822-825.

Thapa, T. B., and V. K. Gupta. 1992. Changes in the sensoric and rheological characteristics during storage of processed cheese foods prepared with added whey protein concentrates. Indian J. Dairy Sci. 45:140-145.

Thomas, M. A. 1973. The Manufacture of Processed Cheese-Scientific Principles. 1st ed. New South Wales Department of Agriculture, Richmond, N.S.W., Australia.

Wiles, P. G., I. K. Gray, and R. C. Kissling. 1998. Routine analysis of proteins by Kjeldahl and Dumas methods: review and interlaboratory study using dairy products. J. AOAC Int. 81:620-632.

Zall, R. R., and Y. A. El-Samragy. 1988. Utilization of salt whey for the production of yeast protein. Cult. Dairy Prod. J. 28-31.

Zayed, G., and J. Winter. 1995. Batch and continuous production of lactic acid from salt whey using free and immobilized cultures of lactobacilli. Appl. Microbiol. Biotechnol. 44:362-366.

Zayed, G., and A. S. Zahran. 1991. Lactic acid production from salt whey using free and agar immobilized cells. Lett. Microbiol. 12:241-243.

Zehren, V. L., and D. D. Nusbaum. 2000. Processed Cheese. 2nd ed. Cheese Reporter Publishing Co. Inc., Madison, WI. 